\title{
Establishment of second-growth forests in human landscapes: ecological mechanisms and genetic consequences
}

\author{
Arndt Hampe $^{1}$ (D) Raquel Alfaro-Sánchez ${ }^{2,3}$ (D) Irene Martín-Forés ${ }^{4,5}$ (D) \\ Received: 18 May 2020 / Accepted: 29 June 2020 / Published online: 2 September 2020 \\ (C) The Author(s) 2020
}

\begin{abstract}
-Key message This special issue gathers articles arising from the ERA-NET BiodivERsA3 research project "Unraveling the Potential of Spontaneous Forest Establishment for Improving Ecosystem Functions and Services in Dynamic Landscapes (SPONFOREST)". Using a broad spectrum of research approaches, they provide detailed insights into how new forest stands establish and which consequences the establishment process has for their character and functioning.
\end{abstract}

Keywords European Green Deal · landscape defragmentation · passive restauration · rural abandonment · spontaneous forest regeneration

The situation of the world's forests has changed dramatically over the last decades. Extensive land use change, global warming, and other anthropogenic drivers have caused major

Handling Editor: Erwin Dreyer

Contributions of the co-authors All co-authors contributed to the text and approved its final version.

This article is part of the topical collection on Establishment of second-growth forests in human landscapes: ecological mechanisms and genetic consequences

Arndt Hampe

arndt.hampe@inrae.fr

Raquel Alfaro-Sánchez

r.alfarosanchez@gmail.com

Irene Martín-Forés

imfores@pdi.ucm.es

INRAE, Univ. Bordeaux, BIOGECO, F-33610 Cestas, France

2 CREAF, Centre de Recerca Ecològica i Aplicacions Forestals E08193 Bellaterra, Cerdanyola de Vallès, Catalonia, Spain

3 Department of Biology, Wilfrid Laurier University, N2L 3C5, 75 University Avenue W, Waterloo, Ontario, Canada

4 MNCN-CSIC, Biogeography and Global Change, National Museum of Natural Sciences, Madrid, Spain

5 School of Biological Sciences, The University of Adelaide, Adelaide, South Australia 5005, Australia shifts in forest cover, functioning, biodiversity, and service delivery worldwide (Trumbore et al. 2015; Johnstone et al. 2016; Curtis et al. 2018). According to FAO estimates, overall global forest area declined from 41 million to just under 40 million $\mathrm{km}^{2}$ (3.1\%) between 1990 and 2015, while planted forests increased by ca. 1 million $\mathrm{km}^{2}$ accounting now for $7 \%$ of the world's forests (FAO 2016). Other estimates based on fine-scale satellite data yield disparate results: from a net forest cover loss of 1.5 million $\mathrm{km}^{2}$ between 2000 and 2012 (Hansen et al. 2013) or even more (Tropek et al. 2014) to a net gain of 2.2 million $\mathrm{km}^{2}$ between 1982 and 2016 (Song et al. 2018). There is, however, broad agreement that deforestation still prevails in the tropics whereas extratropical regions tend to gain in forest cover. Consequently, the proportion of second-growth forests - that is, forest or woodland areas that have re-established after a loss of the original tree cover-is rapidly increasing across both hemispheres. In the tropics, second-growth forests comprise already more than half of the total forested surface (Lugo 2015).

Europe has historically faced more habitat fragmentation than any other continent, with nearly $30 \%$ of the EU territory being moderately to very highly fragmented (Jaeger et al. 2011). But the region was also the first to undergo a turnaround from diminishing to increasing forest cover, with several countries reaching this so-called 'forest transition' already in the nineteenth century (Kauppi et al. 2018). During the last decades, Europe has experienced the greatest recent proportional gain in tree cover of all continents: estimates range from 
$8000 \mathrm{~km}^{2}$ per year since the 1990 s (FAO 2011) to $28,300 \mathrm{~km}^{2}$ per year between 1982 and 2015 (Song et al. 2018). This trend is largely a consequence of rural abandonment and the concomitant reduction of agricultural surfaces (Fuchs et al. 2012; Potapov et al. 2015; Song et al. 2018; Buitenwerf et al. 2019), and it is expected to continue over the next few decades (Schröter et al. 2005; Navarro and Pereira 2015). The increment in tree cover is in line with European and national policies since forests play a key role in the EU's Biodiversity Strategy 2020 and the upcoming Strategy for Sustainable Development 2030 (European Commission 2019). This engagement reflects the fact that forests are now valued as much for their diverse ecological services and their role in mitigating climate change as for their wood production (Gamfeldt et al. 2013; Lugo 2015; Bastin et al. 2019).

European policy has been quite committed to land conversion by means of active forest restoration and spent several billion euros on the afforestation of agricultural surfaces (Forest Europe 2015; Potapov et al. 2015; SantiagoFreijanes et al. 2018). The European Green Deal, a set of policy initiatives launched in 2019 by the European Commission with the overarching aim of making Europe climate neutral in 2050, foresees to commit further extensive efforts to planting trees and restoring damaged or depleted forests in Europe and beyond. However, at the same time, policymakers have almost completely neglected opportunities for passive restoration of agricultural lands through little managed natural forest regeneration (Navarro and Pereira 2015; Rey Benayas and Bullock 2015). Spontaneous reforestation is a widespread phenomenon in Europe following the rural exodus that many unproductive, economically marginal, or sparsely populated rural landscapes have experienced during past decades. Second-growth forests that establish spontaneously on former farmlands represent a transitional stage from recurrently disturbed and homogeneous to more perennial and diversified landscape elements. They are often hardly perceived as landscape units of their own by local stakeholders, managers, and administrations, and they are usually not systematically managed. Yet, these new forest patches form a network of habitats that act as stepping stones for biodiversity conservation and associated ecosystem functions and services in fragmented landscapes. There is little doubt that spontaneous reforestation can represent a very cost-efficient and politically feasible tool to foster multifunctional, diverse landscapes when active management is not possible (Navarro and Pereira 2015; Perino et al. 2019). Yet, the phenomenon has to date received little attention from ecological and forest research as well as policy makers. Research has primarily focused on habitat loss, fragmentation, forest management practices and biodiversity of standing forests, and less on processes of autonomous habitat creation and landscape defragmentation through spontaneous forest regrowth. Politicaladministrative systems have traditionally focused on spatially more extensive managed forests or agricultural lands. In fact, the establishment and expansion of woody vegetation through secondary succession has commonly been conceptualized rather as a challenge than as an opportunity for landscape management and conservation (Eldridge et al. 2011; Navarro and Pereira 2015).

A thorough understanding of forest establishment and its underlying ecological mechanisms is critical for untapping the full potential of second-growth forests in landscape management. Secondary forest succession is often slowed down by diverse biotic and abiotic constraints (Cramer et al. 2008; Cruz-Alonso et al. 2019). Tree establishment is constrained by seed arrival from the surrounding landscape matrix and likely to increase sharply once the founder trees start to reproduce and local seed production becomes abundant (Cramer et al. 2008; Rey Benayas et al. 2008). Tree growth and reproduction change through time, the accompanying vegetation develops, and the communities of associated organisms and their interactions diversify. The establishment process also determines the genetic and phenotypic diversity of the dominant tree species (Troupin et al. 2006; Hampe et al. 2013), which can in turn notably influence the ecosystem functioning of the entire forest patch. Heritable traits of so-called foundation tree species (Ellison et al. 2005) can for instance exert significant effects on net primary production, rates of decomposition and nutrient cycling, structural complexity, or the composition and structure of associated plant and animal communities (Whitham et al. 2006; Allan et al. 2012). On the other hand, an uncontrolled spread of woody vegetation across the landscape can also have numerous undesired effects, including wildfire hazards, the spread of invasive species, or the disappearance of open landscape elements of high conservation value such as oligotrophic grasslands (Rey Benayas and Bullock 2015). Hence, the systematic development of secondgrowth forests as a tool for landscape management hence requires a careful analysis of the ecosystem services and disservices that new forest patches can deliver and of their perception and demand by local population, stakeholders, and the greater public.

Given the quantitative importance of second-growth forests, we still know remarkably little about the ecological processes involved in their establishment and regeneration, as well as their consequences for forest structure, diversity, and functioning. Interestingly, the understanding is currently far more advanced in tropical regions (Barlow et al. 2007; Chazdon and Guariguata 2016) than outside the tropics. The collection of articles assembled in this special issue addresses the biological mechanisms that accompany the establishment of temperate second-growth forests, with a particular focus on the dynamics of the foundation tree species. The issue emerges from ecological and genetic research carried out in the frame of the EU ERA-NET BiodivERsA research project "Unraveling the potential of spontaneous forest establishment

\section{פ̂springer INRAC}


for improving ecosystem functions and services in dynamic landscapes" (SPONFOREST). The project assembled eight research teams from five European countries around five study systems. These systems were located in rural landscapes of South-West Europe, specifically France and Spain. These two countries have experienced a strong expansion of their forest surface over the past decades (France: 35\% since 1945, Tissot and Kohler 2013; Spain: 25\% since 1950, VilàCabrera et al. 2017). The case studies present a wide range of ecological and societal contexts, including the highly fragmented, suburban surroundings of the city of Barcelona as well as very sparsely populated marginal landscapes. In some cases, rural abandonment started already early in the twentieth century and has now passed its peak, whereas in others, it began several decades later and remains significant. Some case studies concern relatively stable and effectively managed landscapes where second-growth forests form small and scattered habitat islands, whereas in others, intense rural abandonment has left large surfaces to forest expansion and a successive closure of the landscape. SPONFOREST addressed two major ecological research questions: (1) How do new forest patches establish within fragmented landscapes?, (2) Which consequences has the establishment process for the genetic and phenotypic diversity of new forest patches and for their functionality at ecosystem level?

The six contributions to this special issue adopt diverse yet highly complementary perspectives to address different aspects of the two overarching questions. Palmero-Iniesta et al. (2020) investigate spatial patterns of forest cover gain in Europe between 1992 and 2015 and how these patterns affect levels of habitat fragmentation and diversity at the landscape scale. They show that the establishment of second-growth forests (planted or spontaneously established) has promoted forest defragmentation both in forest-dominated and nondominated landscapes. The authors also challenge the common notion of forest expansion as single major driver of decreasing landscape diversity (e.g., Marull et al. 2015; Otero et al. 2015). Instead, they draw a more differentiated picture of the evolution of woodland mosaics as a complex phenomenon that involves numerous aspects of landscape composition and location along elevational and geographical gradients across Europe.

Three further studies investigate how patterns of tree regeneration in spontaneously established forest stands influence different components of forest functioning. Gerzabek et al. (2020) monitor early tree recruitment in an expanding Pedunculate oak (Quercus robur) stand and its genetic consequences. They observe extensive recruit mortality that underlies strong habitat-dependent variation. The observed mortality patterns cause a considerable reshuffling in the reproductive success of individual mother trees but have a negligible effect on the stand-scale genetic diversity of the recruiting cohort. The study thus documents the ability of second- growth forests to recover rapidly from genetic founder effects (see also Hampe et al. 2013). Villellas et al. (2020) assess trends in tree genetic and functional trait diversity along a broad colonization front of Spanish juniper (Juniperus thurifera) and test for the existence of genotype-phenotype associations. Sampling a gradient from mature to recently established forest stands, they observe numerous differences in forest structure and tree functional traits. These differences are primarily explained by landscape features and spatial processes while being unrelated with the tree genotypes. Overall, this study underpins the notion that genetic diversity tends to represent a negligible constraint for the functional diversity of actively expanding second-growth forests. Finally, RuízCarbayo et al. (2020) assess patterns of insect leaf herbivory in several second-growth holm oak (Quercus ilex) stands within a fragmented rural landscape and test whether they are related with trees' genetic relatedness, their spatial position within the stand, and a series of functional traits. Contrary to the previous study, these authors do observe an influence of the tree genotype on levels of herbivory; this effect is, however, relatively minor compared with other features of the tree and its ecological neighborhood. Overall, this study highlights that the structural heterogeneity of unmanaged new forests should enhance their function as stepping stones for insect herbivore diversity in fragmented landscapes.

Finally, two tree growth studies complete the special issue with a longer-term perspective upon the dynamics and performance of second-growth forests. Lamonica et al. (2020) develop a spatially explicit growth-neighborhood competition model to investigate how variation in individual tree growth and competition influence the dynamics of spontaneously established forest stands. Applying their model to a tree-ring dataset from several exhaustively sampled Pedunculate oak forest stands in SW France, they observe extensive variation in growth, both within and among stands. Inexistent relationships with the spatial arrangement of trees reflect the individualistic character of the investigated stands. Competition effects are size dependent and widespread but weak and probably not a major constraint for further expansion or densification. Based on the same study system, Alfaro-Sánchez et al. (2020) assess the susceptibility of the oak forest stands to drought episodes in order to elucidate whether ongoing climate change could soon impair the vigorous regional-scale expansion that Pedunculate oak has experienced during past decades. Their study reveals that dominant, coppiced trees are least susceptible to drought periods, suggesting that the 'wild' character of these unmanaged stands, with their uneven age structure and unsystematic exploitation for fire wood, could help enhance their resistance to a warmer and drier climate.

The set of contributions to this special issue illustrates the great complexity and context dependence that characterize the establishment and expansion of second-growth forests. 
European rural landscapes are being transformed at an unprecedented pace following rapid socio-economic and environmental changes that involve both continued intensification and widespread abandonment in different parts of the area. Spontaneous forest regrowth is a reality across Europe that implies risks and opportunities for stakeholders, administrations, and society as a whole. A proper biological understanding of the phenomenon is a prerequisite if we wish to fully exploit its potential as a highly feasible, nature-based solution for restoring biodiversity and multifunctionality in the rural and periurban landscapes of the future.

Funding Supported by the project SPONFOREST (codes: BiodivERsA3-2015-58, ANR-16-EBI3-0011, APCIN 2016 0174)

Data availability Data sharing not applicable to this article (no dataset).

\section{Compliance with ethical standards}

Conflict of interest The authors declare that they have no conflict of interest.

Open Access This article is licensed under a Creative Commons Attribution 4.0 International License, which permits use, sharing, adaptation, distribution and reproduction in any medium or format, as long as you give appropriate credit to the original author(s) and the source, provide a link to the Creative Commons licence, and indicate if changes were made. The images or other third party material in this article are included in the article's Creative Commons licence, unless indicated otherwise in a credit line to the material. If material is not included in the article's Creative Commons licence and your intended use is not permitted by statutory regulation or exceeds the permitted use, you will need to obtain permission directly from the copyright holder. To view a copy of this licence, visit http://creativecommons.org/licenses/by/4.0/.

\section{References}

Alfaro-Sánchez R, Valdés-Correcher E, Espelta JM, Hampe A, Bert D (2020) How do social status and tree architecture influence radial growth, wood density and drought response in spontaneously established oak forests? Ann For Sci 77:49. https://doi.org/10. 1007/s13595-020-00949-x

Allan GJ, Shuster SM, Woolbright S, Walker F, Meneses N, Keith A, Bailey JK, Whitham TG (2012) Interspecific indirect genetic effects (IIGEs). Linking genetics and genomics to community ecology and ecosystem processes. In: Takayuki O, Schmitz O, Holt RD (eds) Trait-mediated indirect interactions: ecological and evolutionary perspectives. Cambridge University Press, New York, pp 295-323

Barlow J, Gardner TA, Araujo IS, Ávila-Pires TC, Bonaldo AB, Costa JE, Esposito MC, Ferreira LV, Hawes J, Hernandez MI, Hoogmoed MS (2007) Quantifying the biodiversity value of tropical primary, secondary, and plantation forests. Proc Natl Acad Sci U S A 104: 18555-18560. https://doi.org/10.1073/pnas.0703333104

Bastin JF, Finegold Y, Garcia C, Mollicone D, Rezende M, Routh D, Zohner CM, Crowther TW (2019) The global tree restoration potential. Science 365:76-79. https://doi.org/10.1126/science.aax0848

Buitenwerf R, Sandel B, Normand S, Mimet A, Svenning JC (2019) Land-surface greening suggests vigorous woody regrowth throughout European semi-natural vegetation. Glob Change Biol 24:5789-5801. https://doi.org/10.1111/gcb.14451

Chazdon RL, Guariguata MR (2016) Natural regeneration as a tool for large-scale forest restoration in the tropics: prospects and challenges. Biotropica 48:716-730. https://doi.org/10.1111/btp.12381

Cramer VA, Hobbs RJ, Standish RJ (2008) What's new about old fields? Land abandonment and ecosystem assembly. Trends Ecol Evol 23: 104-112. https://doi.org/10.1016/j.tree.2007.10.005

Cruz-Alonso V, Villar-Salvador P, Ruiz-Benito P, Ibañez I, Rey-Benayas JM (2019) Long-term dynamics of shrub facilitation shape the mixing of evergreen and deciduous oaks in Mediterranean abandoned fields. J Ecol 108:1125-1137. https://doi.org/10.1111/13652745.13309

Curtis PG, Slay CM, Harris NL, Tyukavina A, Hansen MC (2018) Classifying drivers of global forest loss. Science 361:1108-1111. https://doi.org/10.1126/science.aau3445

Eldridge DJ, Bowker MA, Maestre FT, Roger E, Reynolds JF, Whitford WG (2011) Impacts of shrub encroachment on ecosystem structure and functioning: towards a global synthesis. Ecol Lett 14:709-722. https://doi.org/10.1111/j.1461-0248.2011.01630.x

Ellison AM, Bank MS, Clinton BD, Colburn EA, Elliott K, Ford CR, Foster DR, Kloeppel BD, Knoepp JD, Lovett GM, Mohan J (2005) Loss of foundation species: consequences for the structure and dynamics of forested ecosystems. Frontiers Ecol Environ 3:479-486. https://doi.org/10.1890/1540-9295(2005)003[0479:LOFSCF]2.0. $\mathrm{CO} ; 2$

European Commission (2019) Reflection paper towards a sustainable Europe by 2030. https://doi.org/10.2775/67625

FAO (2011) The state of the world's forests. FAO Forestry Department, Rome

FAO (2016) Global Forest Resources Assessment 2015. FAO Forestry Department, Rome

Forest Europe (2015) State of Europe's forests 2015. Ministerial Conference on the Protection of Forests in Europe, Madrid

Fuchs R, Herold M, Verburg PH, Clevers JP (2012) A high-resolution and harmonized model approach for reconstructing and analyzing historic land changes in Europe. Biogeosciences 9:14823-14866. https://doi.org/10.5194/bgd-9-14823-201

Gamfeldt L, Snäll T, Bagchi R, Jonsson M, Gustafsson L, Kjellander P, Ruiz-Jaen MC, Fröberg M, Stendahl J, Philipson CD, Mikusiński G (2013) Higher levels of multiple ecosystem services are found in forests with more tree species. Nature Comm 4:1340. https://doi. org $/ 10.1038 /$ ncomms 2328

Gerzabek G, Oddou-Muratorio S, Hampe A (2020) Recruitment of a genotyped seedling cohort in an expanding oak forest stand: diversity, dispersal and performance. Ann For Sci 77:78. https://doi.org/ 10.1007/s13595-020-00979-5

Hampe A, Pemonge MH, Petit RJ (2013) Efficient mitigation of founder effects during the establishment of a leading-edge oak population. Proc R Soc B 280:20131070. https://doi.org/10.1098/rspb.2013. 1070

Hansen MC, Potapov PV, Moore R, Hancher M, Turubanova SA, Tyukavina A, Thau D, Stehman SV, Goetz SJ, Loveland TR, Kommareddy A (2013) High-resolution global maps of 21 stcentury forest cover change. Science 342:850-853. https://doi.org/ 10.1126/science. 1244693

Jaeger JA, Soukup T, Schwick C, Madriñán LF, Kienast F (2011) Landscape fragmentation in Europe. In: Feranec J, Soukup T, Hazeu G, Jaffrain G (eds) European landscape dynamics CORINE land cover data. CRC Press, Boca Raton, pp 157-198

Johnstone JF, Allen CD, Franklin JF, Frelich LE, Harvey BJ, Higuera PE, Mack MC, Meentemeyer RK, Metz MR, Perry GL, Schoennagel T (2016) Changing disturbance regimes, ecological memory, and forest resilience. Frontiers Ecol Environ 4:369-378. https://doi.org/10. $1002 /$ fee. 1311 
Kauppi PE, Sandström V, Lipponen A (2018) Forest resources of nations in relation tohuman well-being. PLoS One 13:e0196248. https://doi. org/10.1371/journal.pone.0196248

Lamonica et al. (2020) Tree potential growth varies more than competition among spontaneously established forest stands of Pedunculate oak (Quercus robur). Ann For Sci 77:80. https://doi.org/10.1007/ s13595-020-00981-x

Lugo AE (2015) Forestry in the Anthropocene. Science 349:771. https:// doi.org/10.1126/science.aad2208

Marull J, Otero I, Stefanescu C, Tello E, Miralles M, Coll F, Pons M, Diana GL (2015) Exploring the links between forest transition and landscape changes in the Mediterranean. Does forest recovery really lead to better landscape quality? Agrofor Syst 89:705-719. https:// doi.org/10.1007/s10457-015-9808-8

Navarro LM, Pereira HM (2015) Rewilding abandoned landscapes in Europe. In: Pereira HM, Navarro LM (eds) Rewilding European landscapes. Springer, Cham, pp 3-23

Otero I, Marull J, Tello E, Diana GL, Pons M, Coll F, Boada M (2015) Land abandonment, landscape, and biodiversity: questioning the restorative character of the forest transition in the Mediterranean. Ecol Soc 20:7. https://doi.org/10.5751/ES-07378-200207

Palmero-Iniesta M, Espelta JM, Gordillo J, Pino J (2020) Changes in forest landscape patterns resulting from recent afforestation in Europe (1990-2012): defragmentation of pre-existing forest versus new patch proliferation. Ann For Sci 77:43. https://doi.org/10.1007/ s13595-020-00946-0

Perino A, Pereira HM, Navarro LM, Fernández N, Bullock JM, Ceauşu S, Cortés-Avizanda A, van Klink R, Kuemmerle T, Lomba A, Pe'er G, Plieninger T, Rey Benayas JM, Sandom CJ, Svenning JC, Wheeler HC (2019) Rewilding complex ecosystems. Science 364:eaav5570

Potapov PV, Turubanova SA, Tyukavina A, Krylov AM, McCarty JL, Radeloff VC, Hansen MC (2015) Eastern Europe's forest cover dynamics from 1985 to 2012 quantified from the full Landsat archive. Remote Sens Environ 159:28-43. https://doi.org/10.1016/j. rse.2014.11.027

Rey Benayas JM, Bullock JM (2015) Vegetation restoration and other actions to enhance wildlife in European agricultural landscapes. In: Pereira HM, Navarro LM (eds) Rewilding European landscapes. Springer, Cham, pp 127-142

Rey Benayas JMR, Bullock JM, Newton AC (2008) Creating woodland islets to reconcile ecological restoration, conservation and agricultural use. Frontiers Ecol Eviron 6:329-336. https://doi.org/10.1890/070057

Ruíz-Carbayo H, Pino J, Bonal R, James PM, Hampe A, Molowny-Horas R, Espelta JM (2020) Insect herbivory in novel Quercus ilex L. forests: the role of landscape attributes, forest composition and host traits. Ann For Sci 77:32. https://doi.org/10.1007/s13595-020-00934-4
Santiago-Freijanes JJ, Pisanelli A, Rois-Díaz M, Aldrey-Vázquez JA, Rigueiro-Rodríguez A, Pantera A, Vityi A, Lojka B, FerreiroDomínguez N, Mosquera-Losada MR (2018) Agroforestry development in Europe: policy issues. Land Use Pol 76:144-156. https:// doi.org/10.1016/j.landusepol.2018.03.014

Schröter D, Cramer W, Leemans R, Prentice IC, Araújo MB, Arnell NW, Bondeau A, Bugmann H, Carter TR, Gracia CA, Anne C (2005) Ecosystem service supply and vulnerability to global change in Europe. Science 310:1333-1337. https://doi.org/10.1126/science. 1115233

Song XP, Hansen MC, Stehman SV, Potapov PV, Tyukavina A, Vermote EF, Townshend JR (2018) Global land change from 1982 to 2016. Nature 560:639-643. https://doi.org/10.1038/s41586-018-0411-9

Tissot W, Kohler Y (2013) Integration of nature protection in Forest policy in France. INTEGRATE Country Report. EFICENT-OEF, Freiburg

Tropek R, Sedláček O, Beck J, Keil P, Musilová Z, Šímová I, Storch D (2014) Comment on "high-resolution global maps of 21st-century forest cover change". Science 344:981. https://doi.org/10.1126/ science. 1248753

Troupin D, Nathan R, Vendramin GG (2006) Analysis of spatial genetic structure in an expanding Pinus halepensis population reveals development of fine-scale genetic clustering over time. Mol Ecol 15: 3617-3630. https://doi.org/10.1111/j.1365-294X.2006.03047.x

Trumbore S, Brando P, Hartmann H (2015) Forest health and global change. Science 349:814-818. https://doi.org/10.1126/science. aac6759

Vilà-Cabrera A, Espelta JM, Vayreda J, Pino J (2017) “New forests” from the twentieth century are a relevant contribution for $\mathrm{C}$ storage in the Iberian Peninsula. Ecosystems 20:130-143. https://doi.org/10.1007/ s10021-016-0019-6

Villellas J, Martín-Forés I, Mariette S, Massot M, Guichoux E, AcuñaMíguez B, Hampe A, Valladares F (2020) Functional distance is triggered more strongly by environmental factors than by genetic relatedness in expanding Juniperus thurifera forest stands. Ann For Sci 77:66. https://doi.org/10.1007/s13595-020-00973-x

Whitham TG, Bailey JK, Schweitzer JA, Shuster SM, Bangert RK, LeRoy CJ, Lonsdorf EV, Allan GJ, DiFazio SP, Potts BM, Fischer DG (2006) A framework for community and ecosystem genetics: from genes to ecosystems. Nat Rev Genet 7:510-523. https://doi. org/10.1038/nrg1877

Publisher's note Springer Nature remains neutral with regard to jurisdictional claims in published maps and institutional affiliations. 